\title{
Soil organic carbon content at a range of north Australian tropical savannas with contrasting site histories
}

Xiaoyong Chen ${ }^{1,4}$, Lindsay B. Hutley ${ }^{2}$ and Derek Eamus ${ }^{3}$

\author{
${ }^{1}$ Department of Earth and Environmental Science \\ Okanagan University College \\ 3333 College Way \\ Kelowna, British Columbia V1V 1V7 \\ Canada
}

${ }^{2}$ School of Science and Primary Industries

Faculty of Education, Health and Science

Charles Darwin University

Darwin NT 0909

Australia

${ }^{3}$ Institute for Water and Environmental Resource Management

University of Technology, Sydney

PO Box 123, Broadway

Sydney NSW 2007

Australia

${ }^{4}$ Corresponding author: Tel: (250)762-5445 ext.7887; Fax: (250)470-6004;

E-mail: xchen@ouc.bc.ca 


\section{Abstract}

Soils play an important role in the global carbon cycle, and can be major source or sink of $\mathrm{CO}_{2}$ depending upon land use, vegetation type and soil management practices. Natural and human impact on soil carbon concentration and storage is poorly understood in native north Australian savanna, yet this represents the larges carbon store in the ecosystem. To gain understanding of possible management impacts on this carbon pool, soil organic carbon (SOC) of the top $1 \mathrm{~m}$ of red earth sands and sandy loams common in the region was sampled at 5 sites with different vegetation cover and site history (fire regime and tree removal). SOC was high when compared to other published values for savannas and were more comparable with dry-deciduous tropical forests. Sites sampled in this study represent high rainfall savannas of northern Australia (> $1600 \mathrm{~mm}$ annual rainfall) that feature frequent burning ( 2 in 3 years or more frequent) and a cycle of annual re-growth of tall $\mathrm{C}_{4}$ grasses that dominate the savanna understorey. These factors may be responsible for the higher than expected SOC levels of the surface soils, despite high respiration rates. Medium term fire exclusion (15-20 years) at one of the sampled sites (Wildlife Park) dramatically reduced the grassy biomass of the understorey. This site had lower SOC levels when compared to the grass dominated and frequently burnt sites, which may be due to a reduction in detrital input to surface $(0-30 \mathrm{~cm})$ soil carbon pools. Exclusion of trees also had a significant impact on both the total amount and distribution of soil organic carbon, with tree removal reducing observed $S O C$ at depth $(100 \mathrm{~cm})$. Soil carbon content was higher in the wet season than that in the 2dry season, but this difference was 
not statistically significant. Our results indicated that annual cycle of grass growth and wildfire resulted in small carbon accumulation in the upper of the soil, and removal of woody plants resulted in significant carbon losses to recalcitrant, deep soil horizons greater than $80 \mathrm{~cm}$ depth.

Key words: carbon cycling, wet-dry tropics, savannas, Australia, fire, tree clearing 


\section{Introduction}

The amount of carbon (C) in the soils of the world, estimated between 1000-3000 Pg $\left(1 \mathrm{Pg}=10^{15} \mathrm{~g}\right)$, constitutes approximately two-thirds of the C in terrestrial ecosystems and is an important component of the global C cycle (Houghton et al., 1987; Jobbagy and Jackson, 2000; Post et al., 1982). In addition to the large size of this pool, soil C has a strong interaction with the atmosphere and responds to change in land cover and land managerial practices (Jobbagy and Jackson, 2000).

The amount and distribution of SOC affects and is affected by plant production (Jobbagy and Jackson, 2000). Numerous important processes in forest ecosystems, such as nutrient cycling, cation exchange capacity and soil water storage are all strongly influenced by SOC. Carbon storage in soils is a dynamic balance between detrital inputs (primarily litter and dead roots) and organic matter outputs in the form of $\mathrm{CO}_{2}$ efflux from the soil. Generally, in young, rapidly growing forests, the highest rates of C accumulation are observed, whereas in mature forests, C storage in soil approaches a steady state where output nearly equals inputs (Simmons et al., 1996). Cultivation of forestland for agriculture is considered to result in net losses of soil carbon, whereas forest regrowth results in a significant increase in soil carbon content (Thuille et al., 2000).

Globally, the relative distribution of SOC with depth has stronger association with vegetation than ${ }_{4}$ climate, but the opposite is true for 
the total amount of SOC (Jobbagy and Jackson, 2000). Changes in the dominant plant life form or community type (e.g. grasses, shrubs or trees) greatly influence soil C content, chemistry and distribution, as plant life forms differs in litter chemistry, patterns of detrital input and rooting depth (Gill and Burke, 1999). In addition, plant life forms typically differ in the depth and distribution of their root systems (Jackson et al., 1996; Nepstad et al., 1994), which influences the amount and distribution of soil C. In a study assessing the amount and distribution of soil C below woody vegetation and grasses, Gill and Burke (1999) reported that there was significantly more soil C beneath woody communities than grass dominated ecosystems and the invasion of grasses into shrub-lands influenced the soil C content of only the upper $30 \mathrm{~cm}$ of the soil profile.

Temperature and moisture are two critical environmental factors influencing soil respiration and soil C storage. In general, SOC increases with increasing precipitation, decreasing temperature, and decreasing evapotranspiration / precipitation ratio (Amundson et al., 1989; Jobbagy and Jackson, 2000; Post et al., 1982). Soil organic matter varies inversely with temperature at the landscape scale (Arrouays et al., 1995; Tate, 1992). After reviewing a total of 2696 soil profile data sets from almost every terrestrial biome in the world, Post et al. (1982) reported that warm temperate and dry tropical forests generally had the smallest soil C content, while wet boreal and tropical forests had the largest values.

With structural complexity in tree-grass composition, a history of frequent fires and marked wet and dry seasons and a range of land use pressures, savannas have a 5potentially dynamic SOC. The 
composition and density of trees and grasses in savannas affects both above- and below-ground production, quality of litterfall and vertical root distribution (Belsky, 1994; Priess et al., 1999; Walker et al., 1972), which controls organic $C$ inputs to the soil. Fire can increase or decrease primary production and SOC in savanna ecosystems, depending on fire frequency, intensity and interval time (Anderson et al 2004, Bird et al., 2000). For sites in sub-tropical savanna of Zimbabwe, Bird et al. (2000) observed that reduced fire frequencies resulted in $10 \%$ increase in SOC of the top $0-5 \mathrm{~cm}$ soil, while higher fire frequencies resulted in a $10 \%$ decrease. Total exclusion of fire over a 50-year period resulted in a 40 $50 \%$ increase in soil C.

Given the seasonal nature of climate in savanna regions, there is typically a distinct seasonal trend in soil $\mathrm{CO}_{2}$ efflux, fine root production and litterfall (Chen et al. 2002, Cavelier et al., 1999; Keith et al., 1997; Sundarapandian and Swamy, 1996). Such seasonal patterns of C input to the soil have been observed in the tropical savanna of northern Australia (Chen et al., 2002; 2004) and given the strongly seasonal climate, SOC content could also exhibit seasonal changes despite the inherent stability of SOC. There are few published values of SOC storage in northern Australia and there are no studies examining seasonal changes and differences due to site history. In this paper we hypothesise that Eucalypt open-forest savanna, the dominant vegetation of the northern Australia, has greater SOC than a tree-less grassland site, as the former has more detrital inputs (both above- and below-ground) than the latter. Moreover, it is proposed that the vertical distribution of soil $\mathrm{C}$ will be different in the two communities. Given the seasonality of climate and detrital input to the soil, the soil C 6 of the upper soil changes with 
season. The objectives of the present study, therefore, were to (1) provide values of soil C storage for the wet and dry seasons in this tropical ecosystem, (2) determine the influence of plant form (tree-grass savanna or grassland) on soil C storage and distribution and (3) compare SOC at a site where fire has been excluded to sites with a frequent burning regime.

\section{Materials and methods}

\section{Study sites}

Five sites of the Darwin region $\left(12^{\circ} 30^{\prime} \mathrm{S}, 130^{\circ} 45^{\prime} \mathrm{E}\right)$, Northern Territory, Australia, were used in this study. These were Humpty Doo, Howard Springs, the Territory Wildlife Park, located approximately $35 \mathrm{~km}$ southeast of Darwin. The two other sites, a grassland and an adjacent open forest savanna site were situated on the Gunn Point Peninsula, approximately $30 \mathrm{~km}$ to the north of the Howard Springs site. The climate of all sites is similar, wet-dry tropical, with approximate $95 \%$ of the 1700 $\mathrm{mm}$ annual rainfall occurring during the wet season (November to April) and the dry season (May to October) is characterised by little or no rainfall. Solar radiation and temperature are high year-round. Average maximum and minimum temperatures are 31.8 and $24.8{ }^{\circ} \mathrm{C}$, respectively, in the wet season and 30.5 and $20.0{ }^{\circ} \mathrm{C}$, respectively, in the dry season.

Vegetation of the study region is dominated by Eucalypt open-forest and woodland savanna (Fox et al. 2001). Eucalyptus tetrodonta and E.

miniata are the two dominant species occupying the overstorey and they account for approximate $80 \%$ of the 7 tree basal area of $8-10 \mathrm{~m}^{2} \mathrm{ha}^{-1}$ and 
$75 \%$ of standing biomass of $5.5 \mathrm{~kg} \mathrm{~m}^{-2}$ (O'Grady et al., 2000). Overstorey LAl ranges from 0.6 during the dry season to 1.0 during the wet season (O'Grady et al., 2000). Sub-dominant tree species include Erythrophyleum chlorostachys, Terminalia ferdinandiana, Eucalyptus porrecta and Eucalyptus bleeseri. The understorey is dominated by annual grasses such as Sorghum spp. and to a lesser extent, perennial grasses, plus semi-deciduous and deciduous small trees and shrubs. The annual grass growth occurs during the wet season, with understorey LAI reaching 1.5 by February-March (Hutley, unpublished data), giving a total seasonal range of LAI in these savannas of 2.5 , declining to 0.6 by the dry season. This vegetation type was found at the Howard Springs, Humpty Doo and savanna site at Gunn Point. Savanna vegetation at the fireexcluded Wildlife Park site differed, with higher tree canopy (18 m), lower tree density and greatly reduced occurrence of annual grasses with a higher density of understorey shrub species.

Soils at all sites were typical of the sandy or sandy loam red earths of the Koolpinyah surface (Calder and Day 1982). These soils are extensively weathered and laterised, with low available $\mathrm{N}$ and $\mathrm{P}$ (total $\mathrm{N},<0.1 \%$ Schmidt et al. 1998). The A-horizon is well drained and has a massive and earthy structure. These soils are acidic with $\mathrm{pH}$ ranging from 5.4 to 6 with little variation with depth (Fogarty et al. 1984). Surface clay content is typically $<5 \%$ (Calder and Day 1982), with a gradational transition with depth to a sandy loam or sandy clay loam B-horizon. Between 1-2 m depth, a duricrust of low permeability and variable depth is commonly observed which consisted of ferricrete boulders in a matrix of mottled and heavy clays (Hutley et al., 2000). Prominent macropores, often containing tree roots, are found in 8 this layer. Saturated hydraulic 
conductivity is high ranging from 0.5 to $1 \mathrm{~m} \mathrm{~d}^{-1}$ in surface soils $(0-50 \mathrm{~cm})$ depth (Kelley 2002). The presence of macropores have a significant impact on patterns of deep drainage, with a large range of drainage fluxes observed ( $\sim 0$ to $>3.0 \mathrm{~m} \mathrm{~d}^{-1}$ ). High rates would be due to bypass flow through macropores. Surface gravels of up to $20 \%$ by volume were observed at all sites except the Wildlife Park site where soils were deeper, more uniform in structure, with little or no gravel present. Soils at the study sites are classified as petroferric red Kandosols (Isbell 1996), which equates to the Ferralsols soil group of the FAO-Unesco (1997) soil classification.

There is an annual cycle of grass growth in these savannas and fire occurrence is frequent, although fires are typically cool by Australia standards (Williams et al., 1998). Except for the Wildlife Park site, where fire has been excluded for approximately 15-20 years, the other Eucalypt open-forest sites are subjected to frequent burning, about two years in every three or more frequent, a typical regime of these savannas (Williams et al., 1999). The grassland site has been maintained in a treeless state for approximately 15-20 years (Dr. Dave Bowman person comm.) with grass biomass harvested for hay at irregular intervals and was approximately $0.4-0.5 \mathrm{~kg} \mathrm{~m}^{-2}$, significantly higher than the grass biomass of surrounding open forest savanna $\left(0.2-0.3 \mathrm{~kg} \mathrm{~m}^{-2}\right)$.

Soil samples were collected using a hand auger. At each site, three plots, 100 - $200 \mathrm{~m}$ apart from each other, were chosen for soil sampling. Within each plot, three replicate holes were augured. Soil samples were taken from the augured soil core within each hole at depths of 0-10, 10$20,20-30,30-50,50-80$ and $80-1009 \mathrm{~cm}$, respectively, giving the soil 
depth zones as given in Table 1. Soil samples were brought to the laboratory and passed through a $<2 \mathrm{~mm}$ sieve, then dried in an oven at $60{ }^{\circ} \mathrm{C}$ for 48 hours. After that soil samples were stored in sealed sample jars for preparation for chemical analysis.

In summary, sampling was undertaken at five sites, with three plots at each site randomly selected and three sample holes augured per plot. To express SOC concentration (\%) as a mass per area basis $\left(\mathrm{kg} \mathrm{m}^{-2}\right)$, soil bulk density is required. Soil bulk density data for these red earth soils are available at the Howard Springs study site (Dr. Anthony O'Grady, unpublished data). Bulk density samples were collected from 2 soil pits with soil sampled using ring-samplers of know volume $\left(100 \mathrm{~cm}^{3}\right)$. These two pits were used to sample soils at 40,60, 90 and $110 \mathrm{~cm}$ depths, with between 5 and 3 replicate samples taken for each depth. In addition, for surface soils $(0-5$ and $5-10 \mathrm{~cm}), 5$ replicate samples were taken at the Howard Springs site, with ring samplers hammered into the soil surface ( 5 reps per depth) and a known volume of soil extracted. All samples were dried at $105{ }^{\circ} \mathrm{C}$ to obtain dry weight.

\section{Soil organic carbon analysis}

SOC was determined using an improved Walkley-Black wet digestion method (Heanes, 1984). Approximately $0.5 \mathrm{~g}$ air-dry soil samples (particle size $<0.15 \mathrm{~mm}$ ) were transferred to graduated test tubes with $2 \mathrm{ml}$ of $\mathrm{NK}_{2} \mathrm{Cr}_{2} \mathrm{O}_{7}$ and agitated, with $4 \mathrm{ml}$ of $98 \% \mathrm{H}_{2} \mathrm{SO}_{4}$ gradually added. The test tubes and contents were then heated in an aluminium block at $135{ }^{\circ} \mathrm{C}$ for 30 minutes. Tubes were then allowed to cool to room 
temperature and adjusted to a final volume of $20 \mathrm{ml}$ using distilled water. Blank solutions were prepared in the same way. The soil suspension was then allowed to settle and then the supernatant was centrifuged at $3000 \mathrm{rpm}$ for 15 minutes. Absorbance of all spun supernatant was then measured at $600 \mathrm{~nm}$ and a standard curve constructed of relative absorbency versus organic-C (mg). A series of organic C standard solutions was prepared by dissolving 0.4754 g sucrose in distilled water, dilute to $100 \mathrm{ml}$ and $1 \mathrm{ml}$ of this solution equates to 2 mg organic C. There was a strong relationship between absorbance at 600 $\mathrm{nm}$ and the weight of organic carbon.

\section{Results}

\section{Soil carbon concentration in three Eucalypt open-forest savanna sites}

At the three Eucalypt open-forest savanna sites, soil C concentration decreased from approximately $3.5 \%$ at $5 \mathrm{~cm}$ depth to approximately $0.4 \%$ at $100 \mathrm{~cm}$ depth (Figure 2). The decline in soil C occurred rapidly within the top $30 \mathrm{~cm}$ soil depth and then more gradually from 30 to $100 \mathrm{~cm}$ depth. Among the three sites, Howard Springs had the highest value of soil C concentration, followed by the Humpty Doo site and then the Wildlife Park site with the lowest value. A significant difference $(p<$ 0.01 ) of soil C concentration (\%) occurred in the upper $50 \mathrm{~cm}$ soil depth between Howard Springs and Wildlife Park. There were no significant differences in soil C concentration between the three sites below $50 \mathrm{~cm}$ soil depth. 
The vertical distribution of soil C concentration was similar in both wet and dry seasons at the Eucalypt open-forest sites, although soil C concentration was slightly higher at the end of the wet season (May) than that at the end of the dry season (October) (Figure 1).

Bulk densities of these red earth soils ranged from 1.42 at $5 \mathrm{~cm}$ depth to $1.7 \mathrm{~g} \mathrm{~cm}^{-3}$ at $1 \mathrm{~m}$ (Figure 2) and were similar to values given in Calder and Day (1982) for red earths of the Darwin region. Using bulk densities and C concentration for each sampled depth, total soil C storages in the top $100 \mathrm{~cm}$ of soil for Howard Springs, Humpty Doo and Wildlife Park site for wet season and dry season were given in Table 1 and Table 2, respectively.

Over half of the total organic $C$ was concentrated in the upper $20 \mathrm{~cm}$ soil layer and approximately $80 \%$ of soil C was found in $0-50 \mathrm{~cm}$ depth in all three Eucalypt open forest sites (Table 1 and Table 2).

To analyze site and seasonal differences specifically, the replicate organic C contents in $\mathrm{kg} \mathrm{C}^{-2}$ for each sampled soil horizon were used. Each $1 \mathrm{~m}$ replicate auger hole at each site was divided into three zones, UPPER $(0-20 \mathrm{~cm}), \operatorname{MID}(30-50 \mathrm{~cm})$ and LOWER $(80-100 \mathrm{~cm})$. In addition, total SOC in $\mathrm{kg} \mathrm{C} \mathrm{m}^{-2}$ for each hole was calculated. Data were arranged in this way for both wet and dry season and analysed as a fixed two-way ANOVA (SITE and SEASON as factors) with depth (UPPER, MID, LOWER) set as a covariate, i.e. SOC varied in a similar fashion with depth at all sites. All data were log transformed to stabilise variances and results are given in Table 3. 
The ANOVA showed both site and seasonal differences and post hoc comparison of means (Tukey HSD tests) revealed significant differences between Howard Springs and Wildlife Park sites for both the wet $(P<$ $0.01)$ and dry seasons $(P<0.01)$. There were no differences between Howard Springs and Humpty Doo sites, nor differences between Humpty Doo and the Wildlife Park, for either season. To examine site and seasonal differences including soil depth, data were also analysed as a 3 factor fixed design with soil depth as a factor (and not a covariate). In general, this analysis showed few differences between sites and season and soil depth, with the only significant differences being found between Howard Springs and Wildlife Park sites for the MID soil depth during the dry season $(P<0.039)$ and for the LOWER depth zone during the wet season $(P<0.021)$. The use of this design runs the risk of a Type I error as there was a significant interaction and conclusions must be treated with caution. Data used in these statistical analyses are given in Figure 3. Total soil C storage did not change significantly between seasons (Figure 3).

\section{Soil carbon content of the grassland and savanna sites}

Figure 4 showed the patterns of soil C concentration (\%) with soil depth for the grassland and adjacent open forest savanna at Gunn Point. Soil C concentration was higher in Eucalypt open-forest than in grassland at all depth zones, with differences particularly large at depth (Figure 4). Total SOC at the savanna site was higher than the adjacent grassland site (Table 3, Figure 5a). The difference between the two communities was $6.8 \mathrm{~kg} \mathrm{~m}^{-2}$, with the mean total SOC $13\left(\mathrm{~kg} \mathrm{~m}^{-2}\right)$ at the grassland site being 
$16.1 \mathrm{~kg} \mathrm{~m}^{-2}$ and at the adjacent savanna site was $22.9 \mathrm{~kg} \mathrm{~m}^{-2}$ (Figure $5 \mathrm{a}$ ). These means were significantly different (one-way ANOVA, $F=17.1, \mathrm{df}=15$, $P<0.001)$.

To examine these differences statistically, values were again converted into SOC $\left(\mathrm{kg} \mathrm{m}^{-2}\right)$ and again grouped into UPPER, MID and LOWER depth zones (Figure 5b). Two-way ANOVA suggested that the MID $(P<0.029)$ and LOWER $(P<0.001)$ soil depths were significantly different.

\section{Discussion}

For most ecosystems, SOC represents the most stable C pool. Change to this C pool is generally slow, occurring at decadal to century time-scales and driven by changes in vegetation cover, vegetation type and land use. In savannas, long-term changes in SOC are largely due to changes in fire regime and grazing pressure (Ringrose et al., 1998, Northup and Brown, 1999). In this study, estimates of SOC were undertaken in savanna ecosystems of varying fire history (frequently burnt, Howard Springs, Humpty Doo vs unburnt, Wildlife Park) and structure (grassland vs adjacent open forest savanna). By examining such a set of sites, the range of the soil C pool can be established and can be incorporated into a savanna C balance (e.g. Chen et al. 2003).

Generally savannas have a low SOC content when compared to tropical forest or temperate grasslands (Montgomery and Askew, 1983; Scholes and Hall, 1996). However, values of 14 SOC at the sites sampled in this 
study were higher than those typically found in savannas. The organic $C$ concentration of surface soils $(0-10 \mathrm{~cm}$ depth) had a mean of approximately $3.5 \%$ and in general were higher than the limited data available for soils of the humid savannas in the Darwin region. For surface soils $(0-10 \mathrm{~cm})$, Fogarty et al. (1984) gave values ranging from $1.2 \%$ to $3.5 \%$ SOC for soils from $0-10 \mathrm{~cm}$ depth for a number of red earth soil types supporting E. tetrodonta and E. miniata open-forest, as sampled in this study. They also reported a value of $4.2 \%$ for a massive grey earth, higher than values found in this study, although these soils tend to be waterlogged during the wet season and supported a dense covering of grass and sedge growth which may account for the SOC being higher than that of the well drained red earths. However, it is unlikely that waterlogging is the cause of high SOC values as reported for the red earth soils of the current study, as these soils are well drained. Ponding has been observed during monsoonal downpours but waterlogging is short-lived (hours) and excess water drains away. Calder and Day (1982) also reported values of $2.4 \%$ for surface soils of a red earth of the Douglas-Daly region of the Northern Territory $(150 \mathrm{~km}$ south of the present study sites, receiving a lower annual rainfall of approximately $1300 \mathrm{~mm})$. Values of SOC (\%) at depth $(>50 \mathrm{~cm})$ in the present study were also higher than those given by Fogarty et al. (1984).

SOC tends to be more than three-quarters of the total ecosystem C stocks in woodlands and savannas (Scholes and Hall, 1996). The SOC density in these Eucalypt open forest savannas $\left(15 \pm 3.3 \mathrm{~kg} \mathrm{C} \mathrm{m}^{-2}\right)$ was higher than the global savanna mean $\left(5.7 \pm 4.6 \mathrm{~kg} \mathrm{C} \mathrm{m}^{-2}\right)$ but was similar to the mean for tropical woodlands $\left(11.8 \pm 5.4 \mathrm{~kg} \mathrm{C} \mathrm{m}^{-2}\right)$ as given by Scholes and Hall (1996). The high levels of SOC of 15these savannas may reflect the 
high below-ground $\mathrm{C}$ allocation and productivity, mainly due to fine root growth during the wet season. At the Howard Springs site, below-ground biomass allocation was $57 \%$ of total vegetation biomass, a high value for woody dominated ecosystems (Chen et al 2003). Despite high year to year variation in annual rainfall (Taylor and Tulloch, 1985, Cook and Heerdegen 2001), grass growth in the understorey and the large annual flushing of fine roots in these savanna (Chen et al 2004) occurs every year and represents a significant sequestration of carbon, both aboveand below-ground (approximately $0.6 \mathrm{~kg} \mathrm{C} \mathrm{m}^{-2} \mathrm{y}^{-1}$ ). While above-ground grass biomass is lost to fire, the annual below-ground biomass is not fire affected and this results in detrital accumulation in excess of soil respiration. At the Howard Springs and Wildlife Park sites, measurements of litterfall and net root production have been made (Chen et al., 2003; 2004) plus estimates of soil respiration (Chen et al., 2002). During the study period of 1999 to 2001, C inputs to the soil via litterfall and root production less losses due to soil respiration resulted in a net soil $\mathrm{C}$ exchange of $0.07 \mathrm{~kg} \mathrm{C} \mathrm{m}^{-2} \mathrm{y}^{-1}$, suggesting a small annual net accumulation of SOC. The significant woody component of these savannas (evergreen trees to $16 \mathrm{~m}$ in height, 700 trees per ha) includes deep rooted evergreen trees that are able to contribute to the SOC pool, especially at depth (1 m, Figure 4). Sites used by Scholes and Hall (1996) to derive global mean savanna SOC tend to have lower rainfall than those of this study, which have a wet season rainfall in excess of $1600 \mathrm{~mm}$. Soil $\mathrm{C}$ reported in this study therefore represents a measure of SOC in one of the wetter savanna sites in the world.

Site differences - tree removal 
Savanna vegetation of sites examined in this study has different structure (presence/absence of trees and grass), due to differing fire history or past tree removal. Although the amount of SOC at the grassland site was within the range of SOC of the other three sites (Howard Springs, Humpty Doo and Wildlife Park), the value of the grassland site is significant lower (ANOVA, $F=17.1, \mathrm{df}=15, \mathrm{P}<0.01$ ) than that of the adjacent Eucalypt open forest savanna. This suggests that the presence of trees results in an increase of SOC, which is consistent with the finding of Gill and Burke (1999). They reported that there was significantly more organic C stored in soils beneath woody plants than beneath grass-dominated sites in the semi-arid savannas of Texas and Utah, USA. This $30 \%$ increase in SOC in the tree-grass savanna of Gunn Point is attributable to increases in C input to the soil from grass plus tree litterfall, root production and turnover from the deep-rooted evergreen trees.

\section{Site differences - fire exclusion}

The amounts of SOC at the Humpty Doo and Wildlife Park sites were approximately $80 \%$ and $64 \%$ of that at Howard Springs, respectively (Table 1 and Table 2), and differences between Howard Springs and the Wildlife Park sites were statistically different (Table 3). Soil organic content at Humpty Doo was lower than that at the Howard Springs site, possible due to lower stand density at Humpty Doo, although these differences were not statistically significant.

The significant differences in SOC between the Howard Springs and Wildlife Park are likely to be due to fire history, as the Wildlife Park has had fire excluded for more than 15 17years, whereas savanna at the 
Howard Springs site is burnt approximately twice every 3 years. Little is known of the impacts of fire on SOC pools in tropical savanna (Bird et al., 2000). Most studies suggest frequent fire reduces soil C pools over time (decadal to century time scales), through changes to above-ground vegetation dynamics, their detrital inputs to the SOC pool and root biomass. Fire reduction favours woody re-growth and thickening while increased fire frequency favours a grass-dominated savanna. Fire can also influence soil microbial populations, inorganic and organic nutrient levels (especially nitrogen cycling, Andersson et al. 2004) and can alter soil hydraulic properties (Poth et al., 1995). Daly et al. (2000) simulated root distributions of tree-grass systems and the influence of fire and found that shallow-rooted grasses resulted in smaller soil $C$ pools over the long term. Bird et al. (2000) examined fire impacts on SOC in subtropical savanna of Zimbabwe and found a 40-50 \% increase in soil $C$ in 50-year-old fire exclusion plots. However, decreases of only $10 \%$ were observed in plots where the fire frequency had been reduced rather than fire excluded.

In contrast to the studies cited above, exclusion of fire for 15 years or more from the Wildlife Park significantly reduced the SOC when compared with the frequently burnt Howard Springs site. This difference in sites was apparent during both the wet season and dry season. The exclusion of fire at the Wildlife Park also reduced the annual grass biomass to almost zero and increased woody shrubs in the understorey. When compared to trees, grasses tend to have a shallow rooting system (Jackson et al. 1996), which reduces the vertical SOC distribution (Trumbore, 2000). Detrital input from shallow rooted grasses $(0-30 \mathrm{~cm}$ ) can be inferred from the higher $18 \mathrm{SOC}$ levels of the upper soil zone of 
the burnt site (Howard Springs) compared to the Wildlife Park (ANOVA $F=5.28, d f=12, P<0.021)$.

Considering the entire soil profile, the complete removal of trees at the Gunn Point sites resulted in a $30 \%$ decline in total SOC, with the soil C content of the adjacent savanna $\left(22.9 \mathrm{~kg} \mathrm{~m}^{-2}\right)$ being significantly higher than the grassland site $\left(16.1 \mathrm{~kg} \mathrm{~m}^{-2}\right)$. While removal of trees from these savanna has reduced SOC, removal of annual grasses via fire exclusion has also reduced $\mathrm{SOC}$, at least of the upper soil horizons $(0-50 \mathrm{~cm})$. In humid tropical savannas of northern Australia, the high temperatures and non-limiting available soil water during the growing season results in high annual primary production for grass and fine roots, and the grass dominated understorey makes a large contribution to upper soil organic pools, despite losses due to the impact of fire and high decomposition and respiration rates (Chen et al., 2002). The cycle of fire and vigorous annual grass re-growth may cause an accumulation of organic $\mathrm{C}$ in the soil as primary production of tropical grasses can increase by about $20 \%$ in the season after a fire (Scholes and Hall, 1996). However, such increases may only be observed in the upper soil horizons $(0-30 \mathrm{~cm})$, as reduced tree cover will tend to decrease deep recalcitrant soil C pools (Boutton et al., 1999). Such a trend has been observed in this study, with the amount of SOC at depth $(80-100 \mathrm{~cm})$ at the grassland site $(2.5$ $\mathrm{kg} \mathrm{C} \mathrm{^{-2 }}$ ) being significantly lower than that observed at any of the treedsavanna sites $\left(3-7 \mathrm{~kg} \mathrm{C} \mathrm{m}^{-2}\right)$.

\section{Seasonal differences in soil organic carbon}

In this study a small difference of 19 SOC content (about $10 \%$ ) was 
observed between wet and dry season sampling. Reduced late-dry season SOC (October) would represent cumulative losses from respiration following the low below-ground productivity of the previous 4 to 5 months (June to September). However this seasonal difference was not statistically different (Table 3). Sampling occurred within a single year and large changes to the total soil $C$ were not expected, given the fact that the net flux to the soil $\mathrm{C}$ pool is small relative to the total pool size. In fact, on an annual basis, when inputs from root detritus and litterfall minus soil respiration are considered, there was a small net increase to the total soil $\mathrm{C}$ pool in these savannas of $0.07 \mathrm{~kg} \mathrm{C} \mathrm{m}^{-2} \mathrm{y}^{-1}$, although this change is very small relative to the total soil $\mathrm{C}$ pool of $15.1 \mathrm{~kg} \mathrm{C} \mathrm{m}^{-2}$. Further sampling over a number of wet-dry cycles at a larger number of sites would be required to more thoroughly examine the hypothesis that given the frequent disturbance and seasonal climate, SOC is variable on a short-term basis in this ecosystem.

\section{Conclusions}

We have presented SOC data for a tropical ecosystem subjected to frequent fire with a strongly seasonal climate. These savanna ecosystems are a mosaic of vegetation types due to differing soils, subtle drainage patterns and fire histories. To provide a mean value of SOC store for this ecosystem requires a degree of spatial sampling. We have therefore sampled at savanna sites that represent extremes of this range in terms of site histories (no fire to frequent fire, tree-grass savanna to grassland) to examine the range of values that occur in this 
environment and what impact such factors may have on soil C. The role of tree cover and fire frequency were found to have major impacts on SOC. The annual growth cycle of the $\mathrm{C}_{4}$ grasses also made a large contribution to SOC of the upper soil horizons, despite losses due to fire and high decomposition and respiration rates.

\section{Acknowledgments}

The research was financially support by Cooperative Research Centre for the Sustainable Development of Tropical Savannas (TS-CRC), Northern Territory University (NTU, now Charles Darwin University) and Land and Water Researches Research and Development Corporation (LWRRDC) as grants to Prof. D. Eamus. We also thank Professor David Bowman of the Charles Darwin University, who provided valuable assistance with site selection, Ms Megan Langerveld for great help with the chemical analysis of soil C. X. Chen is grateful to TS-CRC and NTU for the support provided by postgraduate student scholarships.

\section{References}

Amundson R G, Chadwick O A and Sowers J M 1989 A comparison of soil climate and biological activity along an elevational gradient in the eastern Mojave Desert. Oecologia 80, 395-400.

Andersson M, Michelsen A, Jensen M, Kjøller A 2004 Tropical savannah woodland: effects of experimental fire on soil microorganisms and soil emissions of carbon dioxide. Soil 21Biol Biochem 36, 849-858. 
Arrouays D, Vion I and Kicin J L 1995 Spatial analysis and modelling of topsoil carbon storage in temperate forest humic loamy soil of France. Soil Sci. 159, 191-198.

Belsky A J 1994 Influences of trees on savanna productivity: tests of shade, nutrients, and tree-grass competition. Ecology 75, 922-932.

Bird M I, Veenendaal E M, Moyo C, Lloyd J and Frost P 2000 Effects of fire and soil texture on soil carbon in a sub-humid savanna (Matopos, Zimbabwe). Geoderma 94, 71-90.

Calder G J and Day K J 1982 Fertility studies on four soils of the northern lateritic uplands, Northern Territory. Technical Bulletin No. 48, pp. 57. Northern Territory Department of Primary Production.

Cavelier J, Wright S J and Santamaria J 1999 Effects of irrigation on litterfall, fine root biomass and production in a semi-deciduous lowland forest in Panama. Plant and Soil 211, 207-213.

Cook G D, R Heerdegen 2001 Spatial variation in the duration of the rainy season in monsoonal Australia. Int. J. Climatol. 21, 1723-1732.

Chen X, Eamus D and Hutley L B 2002 Seasonal patterns of soil carbon dioxide efflux from a wet-dry tropical savanna of northern Australia. Aust. J Bot. 50, 43-51. 
Chen X, Hutley L B and Eamus D 2003 Carbon balance of a tropical savanna of northern Australia. Oecologia 137, 405-416.

Chen X., Eamus D., Hutley L.B. 2004 Seasonal patterns of fine-root productivity and turnover in a tropical savanna of northern Australia. J Trop. Ecol. 20,221-224

Daly C, Bachelet D, Lenihan J M, Neilson R P, Parton W and Ojima D 2000 Dynamic simulation of tree-grass interactions for global change studies. Ecol. Appl. 10, 449-469.

Fogarty P J, Lynch B and Wood B 1984 The land resources of the Elizabeth, Darwin and Blackmore rivers. Technical Report No. 15, Conservation Commission of the Northern Territory, 98 pages.

FAO-Unesco 1997 Soil Map of the World, Volume X Australia. Paris.

Fox I D, Nelder V J, Wilson G W, Bannink P J 2001 Vegetation of the Australian tropical savannas. Environmental Protection Agency, Brisbane, Queensland.

Gill R A and Burke I C 1999 Ecosystem consequences of plant life form changes at three sites in the semiarid United States. Oecologia 121, 551563.

Heanes D L 1984 Determination of total organic-C in soil by an improved chromic acid digestion and spectrophotometric procedure. Commun. Soil Sci. Plan. 15, 1191-1213. 
Houghton R A, Boone R D, Fruci J R, Hobbie J E, Melillo J M, Palm C A, Peterson B J, Shaver G R and Woodwell G M 1987 The flux of carbon from terrestrial ecosystems to the atmosphere in 1980 due to changes in land use: geographic distribution of the global flux. Teullus 39B, 122-139.

Hutley L B, O'Grady A P and Eamus D 2000 Evapotranspiration from Eucalypt open-forest savanna of Northern Australia. Funct. Ecol. 14, 183 194.

Isbell R F 1996 The Australian soil classification. CSIRO Publishing: Melbourne.

Jackson R B, Canadell J, Ehleringer J R, Mooney H A, Sala O E and Shulze E D 1996 A global analysis of root distribution for terrestrial biomes. Oecologia 108, 389-411.

Jobbagy E G and Jackson R B 2000 The vertical distribution of soil organic carbon and its relation to climate and vegetation. Ecol. Appl. 10, 423 436.

Keith $\mathrm{H}$, Jacobsen K L and Raison R J 1997 Effects of soil phosphorus availability, temperature and moisture on soil respiration in Eucalyptus pauciflora forest. Plant and Soil 190, 127-141.

Kelley G 2002 Tree water use and soil water dynamics in savannas of northern Australia, PhD Thesis, Northern Territory University, 24 
Darwin, 203 pages.

Montgomery R F and Askew G P 1983 Soils of tropical savannas. In Ecosystems of the World 13: Tropical Savannas. Ed. F. Bourliere pp. 63 78. Elsevier, Amsterdam.

Nepsted D C, de Carvalho C R, Davidson E A, Jipp P H, lefebvre P A, Negreiros G H, da Silva E D, Stone T A, Trumbore S E and Vieira S 1994 The role of deep roots in the hydrological and carbon cycles of Amazonian forests and pastures. Nature 372, 666-669.

Northup, B K and Brown J R 1999 Spatial distribution of soil carbon in grazed woodlands of dry tropical Australia: tussock and inner-tussock scales. In: Eldridge, D and Freudenberger, D (eds.), Proceedings of the VIth International Rangeland Congress, Aitkenvale, Queensland. Vol. 1

O'Grady A P, Chen X, Eamus D and Hutley L B 2000 Composition, leaf areas index and standing biomass of eucalypt open forests near Darwin in the Northern Territory, Australia. Aust. J Bot. 48, 629-638.

Post W M, Emanuel W R, Zinke P J and Stangenberger A G 1982 Soil carbon pool and world life zones. Nature 298, 156-159.

Poth M, Anderson I C, Miranda H S, Miranda A C and Riggan P J 1995 The magnitude and persistence of soil $\mathrm{NO}, \mathrm{N} 2 \mathrm{O}, \mathrm{CH} 4$, and $\mathrm{CO}$, fluxes from burned tropical savanna in Brazil. Global Biogeochem. Cy. 9, 503-513.

Priess J, Then C and Folster H 199925 Litter and fine-root production in 
three types of tropical premontane rain forest in SE Venezuela. Plant Ecol. 143, 171-187.

Ringrose S, Matheson W and Vanderpost C 1998 Analysis of soil organic carbon and vegetation cover trends along the Botswana Kalahari transect. J Arid Environ. 38, 379-396.

Schmidt S, Stewart G R, Turnbull M H, Erskine P D and Ashwath N 1998 Nitrogen relations of natural and disturbed plant communities in tropical Australia. Oecologia 117, 95-104.

Scholes R J and Hall D O 1996 The carbon budget of tropical savannas, woodlands and grasslands. In Global Change: Effects on Coniferous Forests and Grassland. Eds A I Breymeyer, D O Hall, J M Melillo and G I Agren. pp. 69-100. John Wiley and Sons Ltd.

Simmons J A, Fernandez I J, Briggs R D and Delaney M T 1996 Forest floor carbon pools and fluxes along a regional climate gradient in Maine, USA. Forest Ecol. Manag. 84, 81-95.

Sundarapandian S M and Swamy P S 1996 Fine root biomass distribution and productivity patterns under open and closed canopies of tropical forest ecosystems at Kodayar in Western Ghats, South India. Forest Ecol. Manag. 86, 181-192.

Tate K R 1992 Assessment, based on a climosequence of soils in tussock grasslands, of soil carbon storage and release in response to global warming. J of Soil Sci. 43, 697-707. 26 
Taylor J A and Tulloch D 1985 Rainfall in the wet-dry tropics: extreme events at Darwin and similarities between years during the period 18701983 inclusive. Aust. J Ecol. 10, 281-295.

Thuille A, Buchmann N and Schulze E D 2000 Carbon stock and soil respiration rates during deforestation, grassland use and subsequent Norway spruce afforestation in the Southern Alps, Italy. Trends Ecol. Evol. 20, 849-857.

Trumbore S 2000 Age of soil organic matter and soil respiration: radiocarbon constraints on belowground C dynamics. Ecol. Appl. 10, 399 411.

Walker J, Moore R M and Robertson J A 1972 Herbage response to tree and shrub thinning in Eucalyptus populnea shrub woodlands. Aust. J Agric. Res. 23, 405-410.

Williams R J, Gill A M and Moore P H R 1998 Seasonal changes in fire behaviour in a tropical savanna in northern Australia. Int. J Wildland Fire. $8,227-239$

Williams R J, Cook G D, Gill A M and Moore P H R 1999 Fire regime, fire intensity and tree survival in a tropical savanna in northern Australia Aust. J Bot. 24, 50-59. 
Table 1. The vertical distribution of soil carbon storage $\left(\mathrm{kg} \mathrm{m}^{-2}\right)$ at three Eucalypt open forest sites in Northern Australia at the end of the wet season (May).

\begin{tabular}{|c|c|c|c|}
\hline Soil depth & Howard Springs & Humpty Doo & Wildlife Park \\
\hline$(\mathrm{cm})$ & Amount & Amount & Amount \\
\hline
\end{tabular}




\begin{tabular}{lllllll}
$0-10$ & 5.3 & 26.8 & 4.9 & 30.8 & 4 & 31.7 \\
$10-20$ & 3.9 & 19.7 & 2.4 & 15.1 & 2.2 & 17.5 \\
$20-30$ & 2.8 & 14.1 & 1.8 & 11.3 & 1.5 & 11.9 \\
$30-50$ & 3.5 & 17.7 & 3.0 & 18.9 & 2.5 & 19.8 \\
$50-80$ & 2.8 & 14.1 & 2.3 & 14.5 & 1.5 & 11.9 \\
$80-100$ & 1.5 & 7.6 & 1.5 & 9.4 & 0.9 & 7.1 \\
Total & 19.8 & 100.0 & 15.9 & 100.0 & 12.6 & 100.0 \\
\hline
\end{tabular}

Table 2. The vertical distribution of soil carbon storage $\left(\mathrm{kg} \mathrm{m}^{-2}\right)$ at three Eucalypt open forest sites in Northern Australia at the end of the dry season (October). 


\begin{tabular}{llllllc}
\hline Soil depth & \multicolumn{2}{c}{ Howard Springs } & \multicolumn{2}{c}{ Humpty Doo } & \multicolumn{2}{c}{ Wildife Park } \\
$(\mathrm{cm})$ & Amount & $\%$ & Amount & $\%$ & Amount & $\%$ \\
\hline $0-10$ & 5.4 & 30.7 & 5 & 36.5 & 3.7 & 33.3 \\
$10-20$ & 3.1 & 17.6 & 2 & 14.6 & 2.1 & 18.9 \\
$20-30$ & 2.5 & 14.2 & 1.5 & 10.9 & 1.2 & 10.8 \\
$30-50$ & 2.9 & 16.5 & 1.5 & 10.9 & 1.7 & 15.3 \\
$50-80$ & 1.9 & 10.8 & 2.2 & 16.1 & 1.5 & 13.5 \\
$80-100$ & 1.8 & 10.2 & 1.5 & 10.9 & 0.9 & 8.1 \\
Total & 17.6 & 100.0 & 13.7 & 100.0 & 11.1 & 100.0 \\
\hline
\end{tabular}

Table 3. Two-way fixed ANOVA for SOC for Howard Springs, Humpty Doo and Wildlife Park sites. In this analysis, depth was set as a covariate. 


\begin{tabular}{lllll}
\hline & df Effect & MS Effect & F & p-level \\
\hline Site & 2 & 1.184 & 23.54 & 0.000 \\
Season & 1 & 0.310 & 6.15 & 0.017 \\
Site * Season & 2 & 0.003 & 0.06 & 0.946 \\
Error & 47 & 0.050 & & \\
\hline
\end{tabular}

Table 4. SOC storage $\left(\mathrm{kg} \mathrm{m}^{-2}\right)$ in Eucalypt open forest and grassland in tropical Northern Australia. 


\begin{tabular}{llcll}
\hline $\begin{array}{l}\text { Soil depth } \\
(\mathrm{cm})\end{array}$ & \multicolumn{2}{l}{ Eucalypt open-forest } & Grassland \\
\hline $0-5$ & Amount & $\%$ & Amount & $\%$ \\
$5-10$ & 3.1 & 13.5 & 2.8 & 17.4 \\
$10-20$ & 2.0 & 8.7 & 1.9 & 11.8 \\
$20-30$ & 3.6 & 15.7 & 3.0 & 18.6 \\
$30-50$ & 2.7 & 11.8 & 2.3 & 14.3 \\
$50-80$ & 4.5 & 19.7 & 3.6 & 22.4 \\
$80-100$ & 4.2 & 18.3 & 1.6 & 9.9 \\
Total & 2.8 & 12.2 & 0.9 & 5.6 \\
\hline
\end{tabular}


Figure 1. Distribution of soil carbon concentration (\%) along the soil profile at the three sites used: (a) at the end of wet season, (b) at the end of dry season. The error bars represent the standard deviation of the mean.

Figure 2. Distribution of soil bulk density along the soil profile at northern Australia. The error bars represent the standard deviation of the mean.

Figure 3. (a) Seasonal and site differences in mean SOC $\left(\mathrm{kg} \mathrm{m}^{-2}\right)$ and (b) and (c) coarse distribution of SOC with depth for sampling during the wet and dry seasons, respectively. The error bars represent the standard deviation of the mean.

Figure 4. Comparison of soil carbon concentration vertical distributions for the Eucalypt open-forest savanna and grassland sites. The error bars represent the standard deviation of the mean.

Figure 5. (a) Site means and standard deviations for the grassland and adjacent savanna sites at Gunn Point. The coarse distribution of soil organic carbon for the two sites is given in (b). 

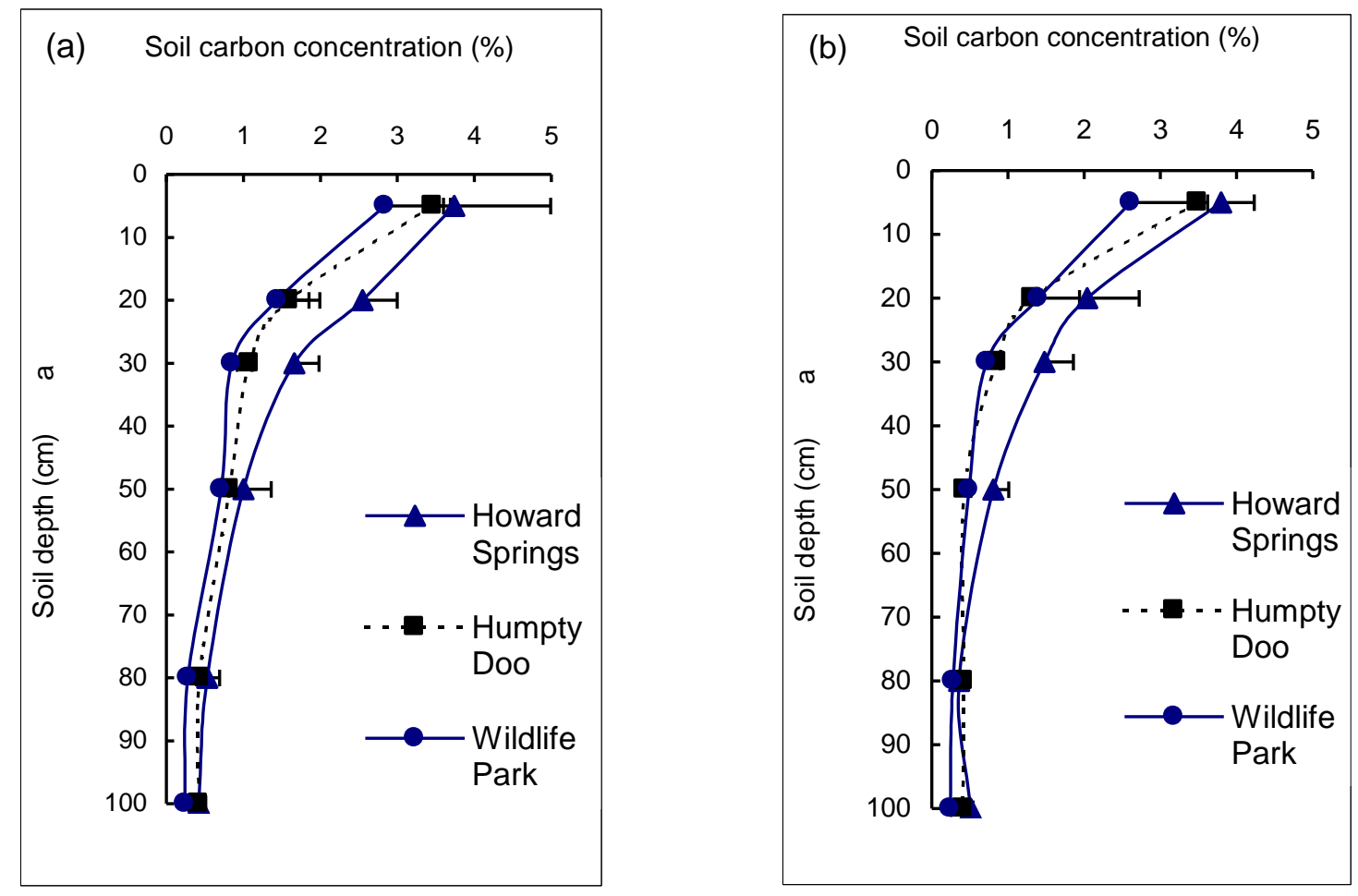

Figure 1. Distribution of soil carbon concentration (\%) along the soil profile at the three sites used: (a) at the end of wet season, (b) at the end of dry season. The error bars represent the standard deviation of the mean. 


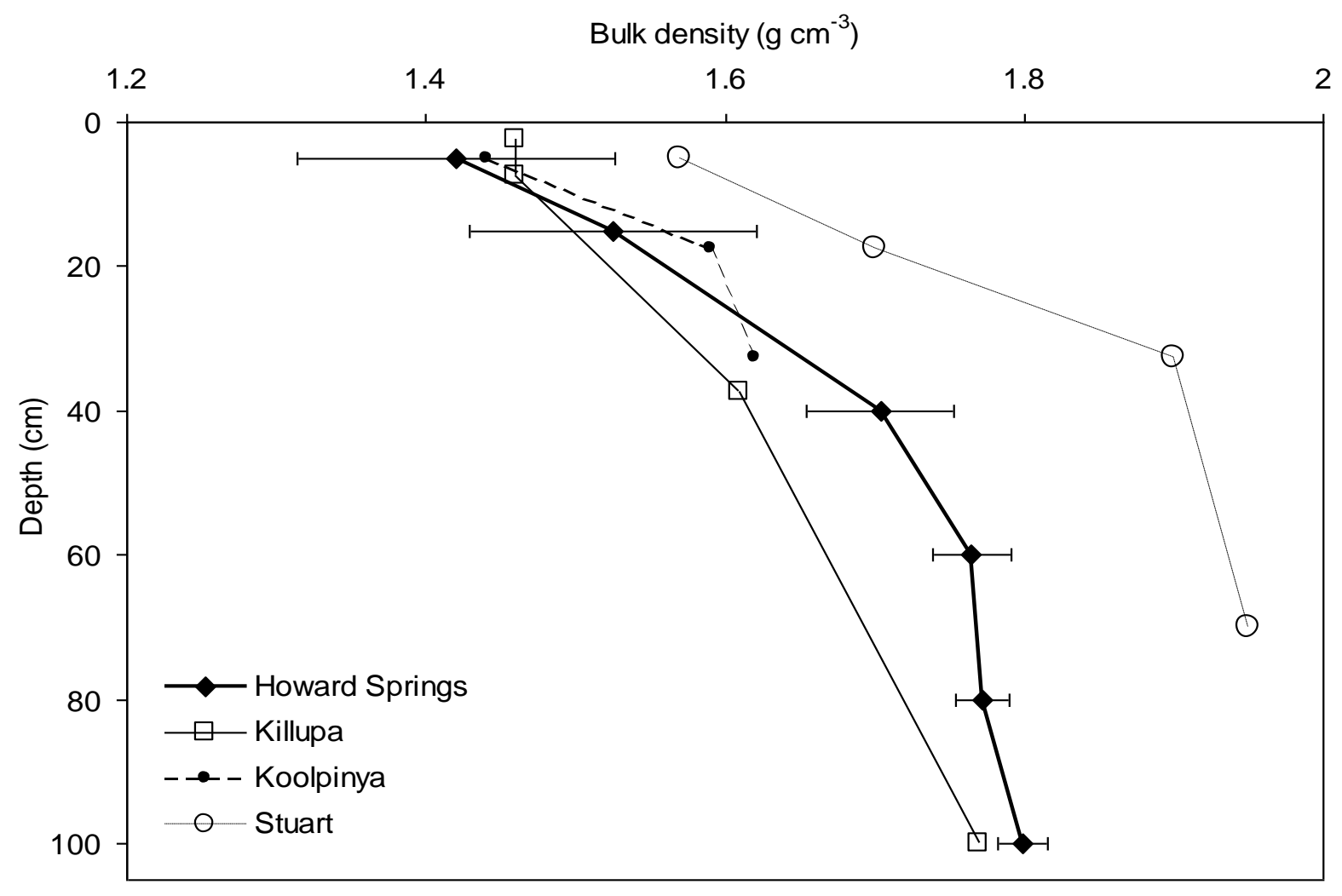

Figure 2. Distribution of soil bulk density with depth for red earth soil at the Howard Springs site. Error bars are the standard deviation of the mean. Comparative data are also given for typical red earth soils of the Koolpinyah surface, 'Killupa', 'Koolpinyah' and 'Stuart' soil types as described by Calder and Day (1982). 

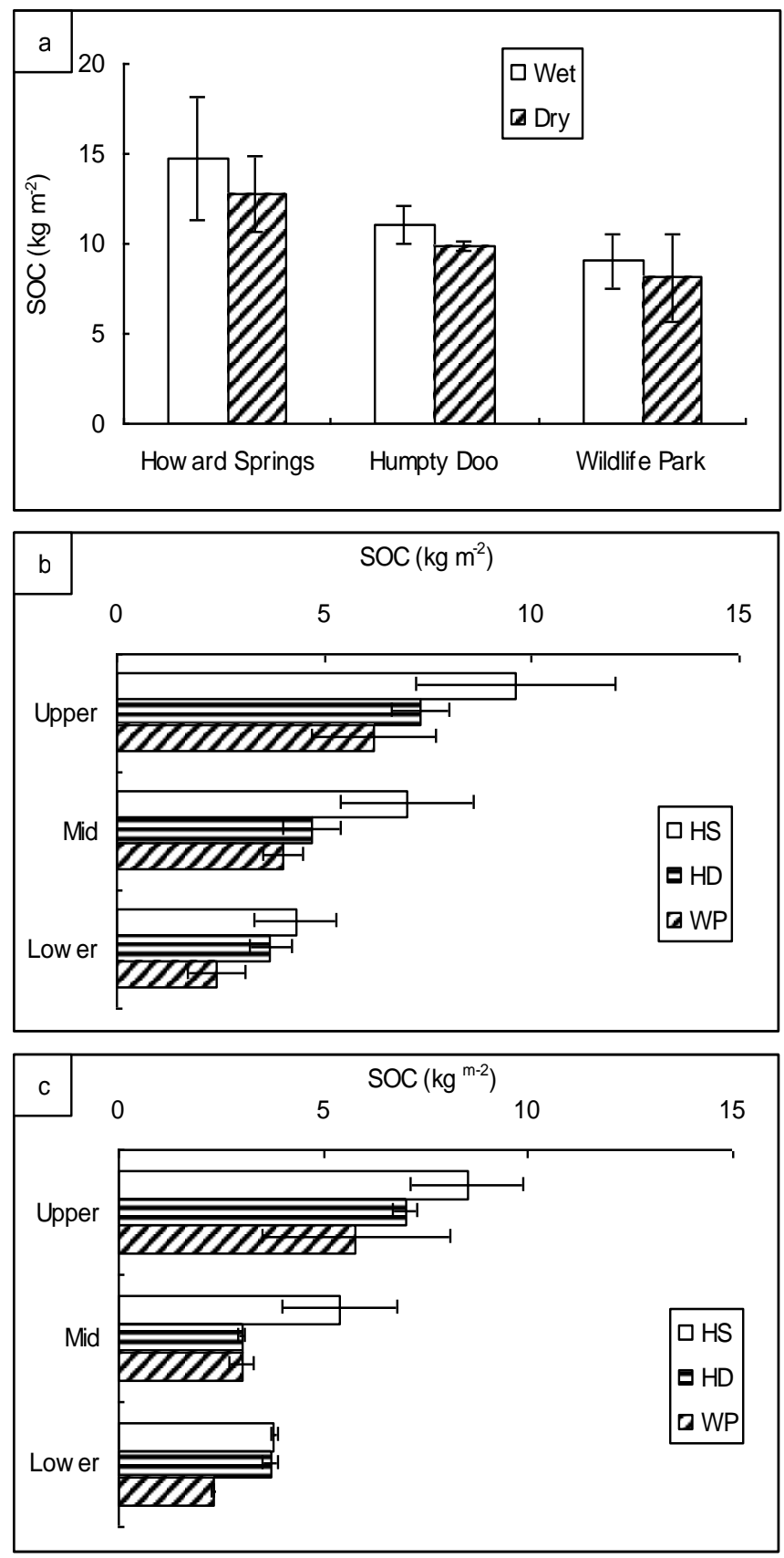

Figure 3. (a) Seasonal and site differences in mean $\operatorname{SOC}\left(\mathrm{kg} \mathrm{m}^{-2}\right)$ and (b) and (c) coarse distribution (UPPER, MID and LOWER) of SOC with depth for sampling during the wet and dry seasons, respectively. The error bars represent the standard deviation of the mean. 


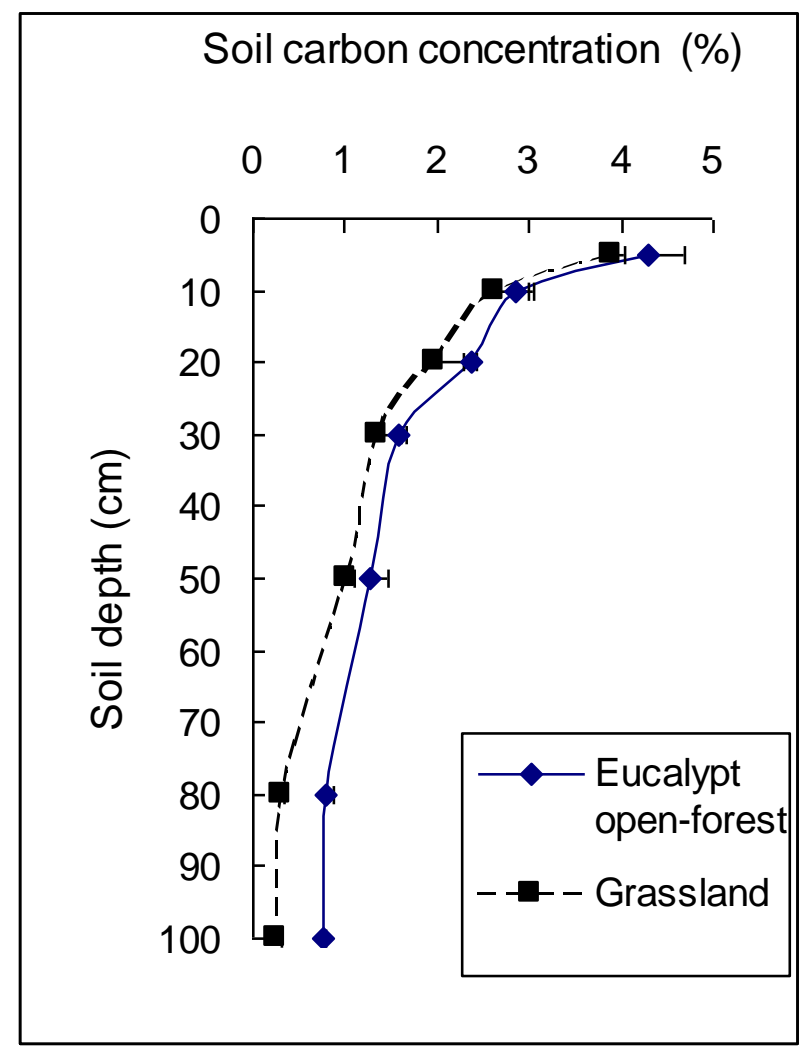

Figure 4. Comparison of soil carbon concentration vertical distributions for the Eucalypt open-forest savanna and grassland sites. The error bars represent the standard deviation of the mean. 

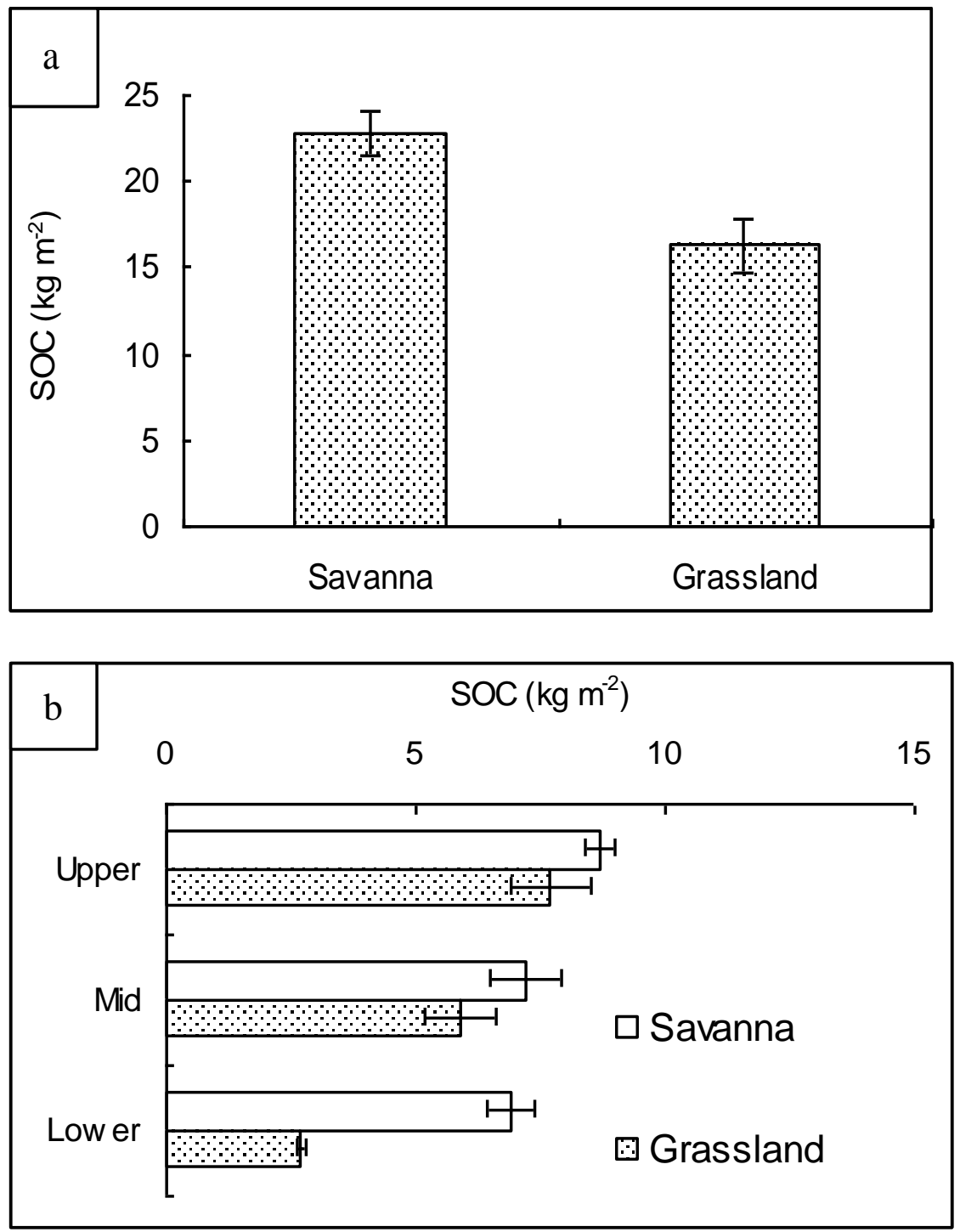

Figure 5. (a) Site means and standard deviations for the grassland and adjacent savanna sites at Gunn Point. The vertical distribution of soil organic carbon for the two sites is given in (b). The error bars represent the standard deviation of the mean. 